\title{
Effect of pre-harvest fungicide treatments on protection against bull's eye rot caused by Neofabraea spp. and residues in apples
}

\author{
Wpływ przedzbiorczego stosowania fungicydów na ochronę jabłek \\ przed gorzką zgnilizną (Neofabraea spp.) oraz pozostałości w owocach
}

\author{
Jolanta A. Szymczak*, Hanna Bryk, Artur Miszczak
}

\begin{abstract}
Summary
Bull's eye rot, caused by Neofabraea spp. is one of the most important fungal diseases of storage apple in Poland. The effectiveness of fungicides: Bellis 38 WG (boscalid, pyraclostrobin) and Switch 62,5 WG (cyprodinil, fludioxonil) in protection against bull's eye rot of cultivar Shampion apples during storage and their residues in apples were investigated. The experiments were conducted in 2012-2014. The fungicides were applied as a single, two and three applications before harvest. After 6 months of storage the biological effectiveness of the fungicides was assessed. The highest effectiveness was obtained after three applications of the tested fungicides; for Switch 62,5 WG - 96.4\% in the season 2012/2013 and 92.7\% in the season 2013/2014, and for Bellis 38 WG -84.7 and $91.0 \%$, respectively. The results of analyses of boscalid, pyraclostrobin, cyprodinil and fludioxonil residues showed that apples contained residues that exceeded $0.01 \mathrm{mg} / \mathrm{kg}$ but below European Union Maximum Residue Levels.
\end{abstract}

Key words: boscalid; pyraclostrobin; cyprodinil; fludioxonil; residues; bull's eye rot

\section{Streszczenie}

Gorzka zgnilizna powodowana przez grzyby rodzaju Neofabraea spp. jest obecnie w Polsce największym zagrożeniem dla jabłek w trakcie ich przechowywania. Celem badań przeprowadzonych w latach 2012-2014 była ocena skuteczności fungicydów: Bellis 38 WG (boskalid, pyraklostrobina) i Switch 62,5 WG (cyprodynil, fludioksonil) w zwalczaniu tej choroby oraz analiza ich pozostałości w owocach. Badane preparaty aplikowano na drzewa odmiany Szampion jednorazowo, dwu-i trzykrotnie przed zbiorem owoców. Po 6 miesiącach przechowywania oceniono biologiczną efektywność fungicydów. Najwyższą skuteczność zaobserwowano po trzykrotnym zastosowaniu badanych środków. W przypadku preparatu Switch 62,5 WG wynosiła ona 96,4\% w sezonie 2012/2013 i 92,7\% w sezonie 2013/2014, a w przypadku Bellis 38 WG odpowiednio: 84,7 i 91,0\%. Wyniki analiz wykazały, że jabłka zawierały powyżej 0,01 mg/kg pozostałości boskalidu, pyraklostrobiny, cyprodynilu i fludioksonilu, lecz poniżej norm obowiązujących w Unii Europejskiej.

Słowa kluczowe: boskalid; pyraklostrobina; cyprodynil; fludioksonil; pozostałości; gorzka zgnilizna jabłek

\author{
Instytut Ogrodnictwa \\ Konstytucji 3 Maja 1/3, 96-100 Skierniewice \\ *corresponding author: Jolanta.Szymczak@inhort.pl
}




\section{Wstęp / Introduction}

Produkcja jabłek w Unii Europejskiej w roku 2014 wynosiła 11,9 mln ton, a w Polsce - 3,5 mln ton (WAPA 2014). Polska zaliczana jest do największych producentów jabłek w Unii Europejskiej (prawie 30\% całkowitej produkcji jabłek) i największych eksporterów tych owoców na świecie (WAPA 2014). Podobnie, jak inne owoce, jabłka są narażone na wiele chorób, zwłaszcza powodowanych przez grzyby, które w konsekwencji powodują straty w zbiorach oraz podczas przechowywania owoców. W polskich warunkach klimatycznych najczęstszą chorobą jest parch jabłoni występujący w okresie wegetacji i gorzka zgnilizna jabłek występująca w czasie przechowywania owoców (Bryk 2010). Gorzką zgniliznę jabłek wywołują grzyby rodzaju Neofabraea spp. (poprzednia nazwa Pezicula spp.). Występuje ona również w innych krajach europejskich (Neri i wsp. 2009; Weber 2009). Choroba ta może powodować znaczne straty podczas przechowywania jabłek sięgające nawet 40\% (Bryk 2010). Ponieważ rynek wymaga dostępności jabłek prawie przez cały rok, bardzo ważne jest odpowiednie zabezpieczenie ich przed chorobami ujawniającymi się $\mathrm{w}$ czasie przechowywania. W produkcji sadowniczej bowiem, priorytetem jest nie tylko uzyskanie plonów o jak najwyższej jakości, ale również utrzymanie tej jakości po zakończonym okresie przechowywania, kiedy owoce trafiają do konsumentów. Na nasilenie występowania gorzkiej zgnilizny jabłek wpływ ma wiele czynników, takich jak: obecność źródła zakażenia w sadzie, wiek drzew, podatność odmiany, warunki pogodowe oraz program ochrony w okresie przedzbiorczym (Bryk 2010). Należy pamiętać, że choroba ta ma ukryty charakter - objawy jej pojawiają się podczas przechowywania jabłek w chłodniach, ale do zakażenia dochodzi znacznie wcześniej w sadzie, jeszcze w okresie wegetacji. Zatem, jeśli choroba wystapiła w danym sezonie to jest duże prawdopodobieństwo, że dojdzie do infekcji w kolejnym sezonie, z uwagi na obecność źródła infekcji w sadzie (Bryk 2010). Także wiek drzew ma wpływ na obecność patogenów - im starsze drzewa tym prawdopodobieństwo rozwoju grzybów na pędach jest większe. Czynnikiem sprzyjającym rozwojowi gorzkiej zgnilizny jabłek jest również przebieg pogody w okresie bezpośrednio poprzedzającym zbiór owoców. Deszcze stymulują rozwój grzybów i sprzyjają zakażeniu jabłek (Bryk 2010). Na rozwój choroby wpływ ma także wybór odmiany większość późnych odmian jabłek wykazuje dużą podatność na tę chorobę (Bryk 2010). Wśród wyżej wymienionych czynników za najważniejsze uważa się warunki sanitarne panujące $\mathrm{w}$ sadzie i zastosowany program ochrony, w następnej kolejności wymienia się wrażliwość odmianową (Dell i Prange 1993; Jones i wsp. 1996; Blažek i wsp. 2006; Poulsen i wsp. 2009; Bryk 2010; Szymczak i wsp. 2013). Najbardziej skutecznym sposobem ochrony jabłek przed chorobami grzybowymi jest stosowanie chemicznych środków ochrony roślin. Blažek i wsp. (2006) wykazali, że zastosowanie fungicydów w sadzie prowadzonym zgodnie $\mathrm{z}$ integrowaną ochroną roślin redukowało nawet czterokrotnie wystąpienie chorób grzybowych w czasie przechowywania w porównaniu do jabłek zebranych $\mathrm{z}$ sadów bez chemicznej ochrony. Jednakże stosowanie chemicznych środków ochrony roślin jest związane z ryzykiem pozostałości pestycydów w owocach (Poulsen i wsp. 2009). Dlatego organy odpowiedzialne za bezpieczeństwo żywności w Unii Europejskiej ustaliły i ciągle aktualizują najwyższe dopuszczalne poziomy pozostałości (NDP) dla wszystkich pestycydów stosowanych w produkcji żywności i pasz (Rozporządzenie 2005).

Biorąc pod uwagę terminy zabiegów, fungicydy, stosowane w celu ograniczenia chorób grzybowych w czasie przechowywania jabłek, stanowią duże ryzyko występowania pozostałości pestycydów w owocach. Do zwalczania chorób grzybowych mogą być użyte zarejestrowane chemiczne środki ochrony roślin. Ostatnio, jako uzupełnienie chemicznej ochrony owoców, coraz bardziej popularne stają się preparaty biologiczne, stosowane przed zbiorem lub też obróbka fizyczna, np. zanurzanie owoców w ciepłej wodzie przed przechowywaniem (Weiss i wsp. 2006; Bryk i Rutkowski 2012). Obecnie w Polsce do chemicznej ochrony jabłek przed gorzką zgnilizną jest zalecanych kilka preparatów (Wyszukiwarka środków ochrony roślin 2015).

Celem badań była ocena dwóch preparatów fungicydowych: Bellis 38 WG (boskalid + pyraklostrobina) i Switch 62,5 WG (cyprodynil + fludioksonil) zastosowanych w różnych terminach przed zbiorem na skuteczność zwalczania gorzkiej zgnilizny w czasie przechowywania jabłek odmiany Szampion oraz poziom pozostałości boskalidu, pyraklostrobiny, cyprodynilu i fludioksonilu w owocach.

\section{Materiały i metody / Materials and methods}

\section{Doświadczenia polowe / Field trials}

Doświadczenia przeprowadzono w czasie dwóch sezonów przechowalniczych 2012/2013 i 2013/2014 w sadzie jabłoniowym położonym w Ostrowcu, w pobliżu Łowicza (centralna Polska) na 10-letnich drzewach odmiany Szampion. Drzewa szczepione były na podkładce M.9 i posadzone w rozstawie $2 \times 4 \mathrm{~m}$. Sad był prowadzony zgodnie $\mathrm{z}$ systemem Integrowanej Produkcji Owoców (IPO). W sadzie prowadzono standardową ochronę drzew przed chorobami (głównie parchem jabłoni) według zaleceń Programu Ochrony Roślin Sadowniczych (PORS). Było to konieczne, ponieważ brak ochrony przed parchem jabłoni spowodowałby brak owoców nadających się do przechowywania. Ochronę przed parchem jabłoni zakończono 1,5 miesiąca przed zbiorem, a właściwe doświadczenia rozpoczęto najwcześniej 21 dni przed zbiorem owoców. Jabłonie były traktowane preparatami: Bellis 38 WG (BASF SE, Niemcy) lub Switch 62,5 WG (Syngenta Crop Protection AG, Szwajcaria) w zalecanych dawkach, odpowiednio: 0,80 i 0,75 kg/ha. Bellis $38 \mathrm{WG}$ zawierał dwie substancje czynne: boskalid $(25,2 \%)$ i pyraklostrobinę $(12,8 \%)$, należące do różnych grup chemicznych i charakteryzujące się różnym mechanizmem działania. Switch 62,5 WG zawierał również dwie substancje czynne o różnym mechanizmie działania: cyprodynil $(37,5 \%)$ i fludioksonil $(25,0 \%)$. Fungicydy nanoszono na drzewa przy użyciu opryskiwacza plecakowo-motorowego typu Stihl z pneumatycznym rozpylaniem cieczy. Dawka 
cieczy roboczej w przeliczeniu na 1 ha wynosiła 7501 , co zapewniało pokrycie cieczą roboczą wszystkich owoców. Badane preparaty były zastosowane następująco: jeden raz - 7 dni przed zbiorem, dwa razy - 7 i 14 dni przed zbiorem, trzy razy - 7, 14 i 21 dni przed zbiorem. W przypadku preparatu Switch 62,5 WG zastosowano dodatkowo jednorazową aplikację 3 dni przed zbiorem. Owoce $\mathrm{z}$ drzew nietraktowanych $\mathrm{w}$ tych terminach żadnymi fungicydami stanowiły kontrolę. Każda kombinacja doświadczalna obejmowała 20 drzew (4 powtórzenia po 5 drzew).

\section{Warunki pogodowe / Weather conditions}

Warunki pogodowe w sadzie (temperatura, opady deszczu) były monitorowane przez automatyczną stację meteorologiczną. Średnie temperatury powietrza i sumę opadów występujących w miesiącach czerwiec-wrzesień przedstawiono w tabeli 1.

\section{Zbiór i przechowywanie owoców / Fruit harvest and storage}

Owoce zbierano jednorazowo w stanie dojrzałości zbiorczej, gdy indeks skrobiowy osiągnął wartość 4-5. W roku 2012 owoce zostały zebrane 17 września, a w roku 2013 - 23 września. Zebrane owoce, po 6 uniwersalnych skrzynek z kombinacji (100 szt. owoców w każdej), przewieziono do chłodni doświadczalnej Instytutu Ogrodnictwa w Skierniewicach, gdzie przechowywano je w warunkach atmosfery normalnej, w temperaturze $2{ }^{\circ} \mathrm{C}$ i wilgotności względnej powietrza $>90 \%$.

\section{Analiza pozostałości pestycydów / Pesticide residues analysis}

Bezpośrednio po zbiorze oraz po zakończeniu przechowywania (6 miesięcy) z każdego powtórzenia pobrano losowo próbki jabłek (10 sztuk w czterech powtórzeniach) i przewieziono do Zakładu Badania Bezpieczeństwa Żywności Instytutu Ogrodnictwa w Skierniewicach w celu przeprowadzenia analizy pozostałości boskalidu, pyraklostrobiny, cyprodynilu i fludioksonilu.

Z owoców, w każdym powtórzeniu wydzielono reprezentatywne próbki analityczne (pobrano ćwiartkę z każdego owocu), które zmielono w obecności suchego lodu. Zmielone próbki analityczne, o masie około 500 g każda, po dokładnym wymieszaniu, dzielono na trzy podpróbki (dwie analityczne i jedną archiwalną) i przechowywano w temperaturze poniżej $-20^{\circ} \mathrm{C}$ przed analizami. $\mathrm{Z}$ tak przygotowanych próbek analitycznych pobierano $10 \mathrm{~g}$ porcje analityczne do analizy pozostałości pestycydów. Pozostałości badanych fungicydów analizowano zgodnie $\mathrm{z}$ metodą PN-EN 15662:2008. Procedura analityczna była następująca: porcję analityczną jabłek o masie $10 \mathrm{~g}$ ekstrahowano $10 \mathrm{ml}$ acetonitrylu (Carlo Erba Reagents S.A.S, Francja) wytrząsając w czasie 1 min. Następnie dodano mieszaninę ekstrakcyjną cytrynianową: $4,0 \mathrm{~g} \mathrm{MgSO}_{4}$ (Sigma Aldrich Chemie $\mathrm{GmbH}$, Japonia), 1,0 g NaCl (Sigma Aldrich Chemie GmbH, USA), $1,0 \mathrm{~g} \mathrm{C}_{6} \mathrm{H}_{6} \mathrm{Na}_{3} \mathrm{O}_{7} \cdot 2 \mathrm{H}_{2} \mathrm{O}$ (Sigma Aldrich Chemie GmbH, Belgia) i 0,5 g C$_{6} \mathrm{H}_{6} \mathrm{Na}_{2} \mathrm{O}_{7}$ - $1,5 \mathrm{H}_{2} \mathrm{O}$ (Sigma Aldrich Chemie $\mathrm{GmbH}$, Niemcy), wy- trząsano przez 1 min i wirowano z prędkością $5500 \times \mathrm{g}$ przez $5 \mathrm{~min}$. Supernatant w ilości $1,0 \mathrm{ml}$ przeniesiono do probówki wirówkowej zawierającej: 0,025 g PSA (Supelco Analytical, USA) i $0,15 \mathrm{~g} \mathrm{MgSO}_{4}$ (Sigma Aldrich Chemie $\mathrm{GmbH}$, Japonia). Po wytrząsaniu przez $1 \mathrm{~min}$ i wirowaniu $5500 \times$ g przez $1 \mathrm{~min}$, przeniesiono $1 \mathrm{ml}$ supernatantu do fiolki i dodano $50 \mu \mathrm{l}$ TPP (Supelco Analytical, USA) jako standard wewnętrzny oraz $100 \mu \mathrm{l}$ acetonitrylu. Po wymieszaniu, ekstrakt analizowano metodą chromatografii gazowej sprzężonej ze spektrometrią mas (GC/MS). Chromatograf gazowy (Agilent Technologies 6890N Network GC System, USA) był wyposażony w spektrometr masowy (Agilent Technologies 5975B inert XL Mass Selective Detector, USA) i komorę nastrzykową typu PTV. Rozdział substancji przeprowadzono na kolumnie kapilarnej DB-5MS, 30,0 m × $250 \mu \mathrm{m} \times 0,25 \mu \mathrm{m}(\mathrm{J} \& \mathrm{~W}$ GC Column, Agilent Technologies, USA). Identyfikację i analizę ilościową docelowych analitów przeprowadzono techniką monitorowania wybranych jonów (SIM). Monitorowane jony $(\mathrm{m} / \mathrm{z})$ metody analitycznej GC-MS przedstawiono w tabeli 2. Metoda została zwalidowana w Zakładzie Badania Bezpieczeństwa Żywności zgodnie z dokumentem SANCO $(2011,2013)$ i jest akredytowana przez Polskie Centrum Akredytacji (Nr akredytacji - AB 757). Najważniejsze dane metody analitycznej zastosowanej do analizy jabłek podano w tabeli 2 .

\section{NDP UE / MRL EU}

Wyniki pozostałości badanych środków ochrony roślin porównano $\mathrm{z}$ najwyższymi dopuszczalnymi poziomami obowiązującymi w Unii Europejskiej (NDP UE), zgodnie z Rozporządzeniem (WE) nr 396/2005. Najwyższe dopuszczalne poziomy pozostałości badanych fungicydów w jabłkach wynoszą: dla boskalidu - 2,0 mg/kg; dla pyraklostrobiny - 0,3 mg/kg; dla cyprodynilu $-1,0 \mathrm{mg} / \mathrm{kg}$ i dla fludioksonilu - 5,0 mg/kg (Rozporządzenie 2005).

Oceniono również, czy jabłka poddane badanym zabiegom będą spełniały wymagania odnośnie pozostałości pestycydów określonych dla niemowląt i małych dzieci (tj. do 3 roku życia). Dla tej grupy żywieniowej, zgodnie z Dyrektywą Komisji 2006/141/WE najwyższy dopuszczalny poziom pozostałości pestycydów wynosi $0,01 \mathrm{mg} / \mathrm{kg}$.

\section{Ocena występowania gorzkiej zgnilizny jabłek Assessment of the incidence of bull's eye rot of apples}

Po 6-miesięcznym okresie przechowywania owoców przeprowadzono ocenę występowania gorzkiej zgnilizny jabłek, licząc w każdej skrzynce owoce zdrowe i z objawami gorzkiej zgnilizny jabłek. Efektywność zastosowanych fungicydów obliczano według wzoru Abbotta:

Efektywność $[\%]=[($ Porażenie owoców w kombinacji kontrolnej) - (Porażenie owoców w kombinacji traktowanej)/Porażenie owoców w kombinacji kontrolnej] $\times 100$

\section{Analiza statystyczna / Statistical analysis}

Wyniki pozostałości badanych fungicydów oraz nasilenie gorzkiej zgnilizny jabłek opracowano statystycznie stosując metodę analizy wariancji R.A. Fischera. Wartości 
procentowe nasilenia gorzkiej zgnilizny jabłek przekształcano według transformacji Blissa. Do oceny różnic między średnimi użyto testu Newmana-Keulsa, przyjmując poziom istotności 5\%.

\section{Wyniki i dyskusja / Results and discussion}

$\mathrm{Na}$ podstawie danych meteorologicznych przedstawionych w tabeli 1. można stwierdzić, że oba sezony badawcze różniły się głównie sumą opadów deszczu w poszczególnych miesiącach, a średnie temperatury były na zbliżonym poziomie. Jednak, biorąc pod uwagę sumę opadów deszczu trudno ocenić wpływ warunków pogodowych na nasilenie zakażenia w poszczególnych latach badań. W lipcu i sierpniu 2013 roku opady deszczu były znacznie niższe niż $w$ tych samych miesiącach w 2012 roku, a nasilenie gorzkiej zgnilizny jabłek było znacznie wyższe, co wykazały wyniki oceny przedstawione $\mathrm{w}$ tabeli 3. We wrześniu, kiedy prowadzono większość zabiegów badanymi fungicydami i zbierano owoce, suma opadów deszczu była na podobnym poziomie w obu sezonach.

Stwierdzono, że zastosowanie środka Bellis $38 \mathrm{WG}$ (boskalid + pyraklostrobina) lub Switch 62,5 WG (cyprodynil + fludioksonil) przed zbiorem jabłek znacznie ograniczało występowanie gorzkiej zgnilizny (spowodo- wanej przez Neofabraea spp.) podczas przechowywania w porównaniu do owoców nietraktowanych - kontroli. W obu sezonach badawczych, dwu- lub trzykrotne zastosowanie fungicydów przed zbiorami skuteczniej hamowało wystąpienie choroby niż jednokrotna aplikacja. Najwyższą skuteczność uzyskano po trzykrotnym użyciu badanych środków; w przypadku Switch 62,5 WG - 96,4\% w sezonie 2012/2013 i 92,7\% w sezonie 2013/2014, a w przypadku Bellis 38 WG odpowiednio: 84,7 i $91,0 \%$ (tab. 3). Fungicyd Switch 62,5 WG zastosowany jednorazowo -7 dni przed zbiorem owoców, istotnie redukował nasilenie choroby, podczas gdy Bellis 38 WG tak zastosowany, nie obniżał istotnie objawów choroby (tab. 3). Podobnie, słabą skuteczność wykazano we wcześniejszych badaniach, kiedy Captan 80 WG i Thiram Granuflo 80 WG zastosowano 7 dni przed zbiorem (Szymczak i wsp. 2013). Jednorazowe użycie środka Switch 62,5 WG na 3 dni przed zbiorem owoców również nie ograniczało istotnie gorzkiej zgnilizny jabłek w czasie przechowywania. Niska skuteczność środków grzybobójczych lub jej brak, po aplikacji 3 lub 7 dni przed zbiorem może być wyjaśniona sposobem infekcji jabłek przez Neofabraea spp. Zarodniki tych grzybów mogą przenikać do jabłek przez przetchlinki przez długi okres czasu przed zbiorem (Spotts 1990). Prawdopodobnie fungicydy stosowane 7 lub 3 dni przed zbiorem nie zapobiegają wcześniejszemu zakażeniu.

Tabela 1. Średnia temperatura i suma opadów deszczu w miesiącach czerwiec-wrzesień 2012 i 2013

Table 1. Mean air temperature and sum of rainfall during June-September 2012 and 2013

\begin{tabular}{|c|c|c|c|c|}
\hline \multirow[t]{2}{*}{$\begin{array}{l}\text { Miesiąc } \\
\text { Month }\end{array}$} & \multicolumn{2}{|c|}{$\begin{array}{c}\text { Średnia temperatura } \\
\text { Mean air temperature } \\
{\left[{ }^{\circ} \mathrm{C}\right]}\end{array}$} & \multicolumn{2}{|c|}{$\begin{array}{c}\text { Suma opadów deszczu } \\
\text { Sum of rainfall } \\
{[\mathrm{mm}]}\end{array}$} \\
\hline & 2012 & 2013 & 2012 & 2013 \\
\hline Czerwiec - June & 16,7 & 17,5 & 64,8 & 152,6 \\
\hline Lipiec - July & 20,2 & 19,2 & 52,2 & 5,8 \\
\hline Sierpień - August & 18,6 & 18,4 & 63,0 & 17,6 \\
\hline Wrzesień - September & 14,2 & 11,5 & 41,4 & 48,0 \\
\hline
\end{tabular}

Tabela 2. Charakterystyka metody analitycznej

Table 2. Performance characteristics of the analytical method

\begin{tabular}{|c|c|c|c|c|c|c|}
\hline \multirow{2}{*}{$\begin{array}{l}\text { Substancja czynna } \\
\text { Active substance }\end{array}$} & \multicolumn{2}{|c|}{$\begin{array}{l}\text { Monitorowane jony } \\
\text { Monitored ions }\end{array}$} & \multicolumn{4}{|c|}{$\begin{array}{c}\text { Wybrane parametry walidacyjne } \\
\text { (wartości średnie } \mathrm{z} \text { dziesięciu pomiarów) } \\
\text { Some validation parameters } \\
\text { (mean values of ten replicate measurements) }\end{array}$} \\
\hline & $\begin{array}{c}\text { jon } \\
\text { ilościowy } \\
\text { quantification } \\
\text { ion } \\
{[\mathrm{m} / \mathrm{z}]}\end{array}$ & $\begin{array}{c}\text { jony } \\
\text { potwierdzające } \\
\text { confirmation ions } \\
{[\mathrm{m} / \mathrm{z}]}\end{array}$ & $\begin{array}{c}\text { granica } \\
\text { oznaczalności } \\
\text { limit of } \\
\text { quantification } \\
{[\mathrm{mg} / \mathrm{kg}]}\end{array}$ & $\begin{array}{l}\text { odzysk } \\
\text { recovery } \\
{[\%]}\end{array}$ & $\begin{array}{c}\text { precyzja } \\
\text { precision } \\
{[\%]}\end{array}$ & $\begin{array}{c}\text { niepewność } \\
\text { rozszerzona } \\
\text { expanded } \\
\text { uncertainty* } \\
{[\%]}\end{array}$ \\
\hline Boskalid - Boscalid & 140 & $142,342,344$ & 0,01 & 103,4 & 6,4 & 12,4 \\
\hline Cyprodynil - Cyprodinil & 224 & 210,225 & 0,01 & 108,4 & 4,2 & 12,6 \\
\hline Fludioksonil - Fludioxonil & 248 & 127,154 & 0,01 & 93,2 & 3,4 & 12,3 \\
\hline Pyraklostrobina - Pyraclostrobin & 132 & 164,1 & 0,01 & 102,0 & 5,0 & 14,8 \\
\hline
\end{tabular}

*podana niepewność jest niepewnością rozszerzoną oszacowaną w laboratorium i obliczoną w oparciu o współczynnik rozszerzenia równy 2 , czyli $z$ około $95 \%$ poziomem ufności - the reported uncertainty is an expanded uncertainty evaluated in the laboratory and calculated using a coverage factor of 2 which gives a level of confidence of approximately $95 \%$ 
Tabela 3. Efektywność fungicydów Bellis 38 WG (boskalid + pyraklostrobina) i Switch 62,5 WG (cyprodynil + fludioksonil) w zwalczaniu gorzkiej zgnilizny jabłek odmiany Szampion w zależności od liczby i terminów zabiegów przed zbiorem

Table 3. Effectiveness of Bellis $38 \mathrm{WG}$ (boscalid + pyraclostrobin) and Switch 62,5 WG (cyprodinil + fludioxonil) in the control of bull's eye rot of apple cultivar Shampion depending on the number and dates of treatments before harvest

\begin{tabular}{l|c|c|c|c|c}
\hline & Terminy zabiegów & \multicolumn{2}{|c|}{$\begin{array}{c}\text { Sezon 2012/2013 } \\
\text { Season 2012/2013 }\end{array}$} & \multicolumn{2}{c}{$\begin{array}{c}\text { Sezon 2013/2014 } \\
\text { Season 2013/2014 }\end{array}$} \\
\cline { 3 - 6 } \multicolumn{1}{c}{$\begin{array}{c}\text { Fungicyd } \\
\text { Fungicide }\end{array}$} & $\begin{array}{c}\text { (dni przed zbiorem) } \\
\text { Dates of treatments } \\
\text { (days before } \\
\text { harvest) }\end{array}$ & $\begin{array}{c}\text { \% jabłek z objawami } \\
\text { gorzkiej zgnilizny } \\
\text { percent of apples } \\
\text { infected by } \\
\text { Neofabraea spp. }\end{array}$ & $\begin{array}{c}\text { efektywność } \\
\text { fungicydów } \\
\text { fungicides } \\
\text { effectiveness } \\
{[\%]}\end{array}$ & $\begin{array}{c}\text { \% jabłek z objawami } \\
\text { gorzkiej zgnilizny } \\
\text { percent of apples } \\
\text { infected by } \\
\text { Neofabraea } \text { spp. }\end{array}$ & $\begin{array}{c}\text { efektywność } \\
\text { fungicydów } \\
\text { fungicides } \\
\text { effectiveness } \\
{[\%]}\end{array}$ \\
\hline Control - Untreated & - & $2,74 \mathrm{~b}$ & - & $11,17 \mathrm{~d}$ & - \\
\hline Bellis 38 WG & $21,14,7$ & $0,42 \mathrm{a}$ & 84,7 & $1,01 \mathrm{a}$ & 91,0 \\
(boskalid + pyraklostrobina) & 14,7 & $0,53 \mathrm{a}$ & 80,7 & $2,66 \mathrm{~b}$ & 76,2 \\
(boscalid + pyraclostrobin) & 7 & $1,00 \mathrm{ab}$ & 63,5 & $8,14 \mathrm{~cd}$ & 27,1 \\
\hline Switch 62,5 WG & $21,14,7$ & $0,10 \mathrm{a}$ & 96,4 & $0,82 \mathrm{a}$ & 92,7 \\
(cyprodynil + fludioksonil) & 14,7 & $0,53 \mathrm{a}$ & 80,7 & $3,64 \mathrm{~b}$ & 67,4 \\
(cyprodinil + fludioxonil) & 7 & $0,69 \mathrm{a}$ & 74,8 & $6,22 \mathrm{c}$ & 44,3 \\
\hline
\end{tabular}

Analiza statystyczna została przeprowadzona oddzielnie dla każdego sezonu. Średnie w kolumnach oznaczone tą samą literą nie różnią się istotnie według testu Newmana-Keulsa przy $\mathrm{p}=0,05$

Statistical analysis was performed separately for each season. Means in the columns followed by the same letter are not significantly different according to the Newman-Keuls test at $\mathrm{p}=0.05$

Tabela 4. Poziom pozostałości boskalidu i pyraklostrobiny w jabłkach odmiany Szampion, po zbiorze i po przechowywaniu, w zależności od liczby i terminów zabiegów preparatem Bellis 38 WG

Table 4. Boscalid and pyraclostrobin residues in apple cultivar Shampion after harvest and after cold storage, depending on the number and dates of Bellis 38 WG treatments

\begin{tabular}{|c|c|c|c|c|c|}
\hline \multirow{3}{*}{$\begin{array}{c}\text { Liczba } \\
\text { zabiegów } \\
\text { The number } \\
\text { of treatments }\end{array}$} & \multirow{3}{*}{$\begin{array}{l}\text { Terminy zabiegów } \\
\text { (dni przed zbiorem) } \\
\text { Dates of treatments } \\
\text { (days before harvest) }\end{array}$} & \multicolumn{2}{|c|}{$\begin{array}{l}\text { Sezon } 2012 / 2013 \\
\text { Season } 2012 / 2013\end{array}$} & \multicolumn{2}{|c|}{$\begin{array}{l}\text { Sezon } 2013 / 2014 \\
\text { Season } 2013 / 2014\end{array}$} \\
\hline & & \multicolumn{4}{|c|}{$\begin{array}{l}\text { terminy analiz pozostałości fungicydów } \\
\text { dates of fungicide residues analyses }\end{array}$} \\
\hline & & $\begin{array}{l}\text { po zbiorze } \\
\text { after harvest }\end{array}$ & $\begin{array}{l}\text { po przechow. } \\
\text { after storage }\end{array}$ & $\begin{array}{l}\text { po zbiorze } \\
\text { after harvest }\end{array}$ & $\begin{array}{l}\text { po przechow. } \\
\text { after storage }\end{array}$ \\
\hline \multicolumn{6}{|c|}{ Pozostałości boskalidu - Boscalid residues $[\mathrm{mg} / \mathrm{kg}]$} \\
\hline $\begin{array}{l}0 \\
3 \\
2 \\
1\end{array}$ & $\begin{array}{c}- \\
21,14,7 \\
14,7 \\
7\end{array}$ & $\begin{array}{l}\quad \text { n.d. } \\
0,310 \mathrm{~b} \\
0,289 \mathrm{ab} \\
0,134 \mathrm{a}\end{array}$ & $\begin{array}{l}\quad \text { n.d. } \\
0,204 \mathrm{~b} \\
0,172 \mathrm{ab} \\
0,092 \mathrm{a}\end{array}$ & $\begin{array}{l}\text { n.d. } \\
0,232 \mathrm{c} \\
0,164 \mathrm{bc} \\
0,083 \mathrm{a}\end{array}$ & $\begin{array}{l}\text { n.d. } \\
0,084 \mathrm{~b} \\
0,063 \mathrm{ab} \\
0,042 \mathrm{a}\end{array}$ \\
\hline \multicolumn{6}{|c|}{ Pozostałości pyraklostrobiny - Pyraclostrobin residues $[\mathrm{mg} / \mathrm{kg}]$} \\
\hline $\begin{array}{l}0 \\
3 \\
2 \\
1\end{array}$ & $\begin{array}{c}- \\
21,14,7 \\
14,7 \\
7\end{array}$ & $\begin{array}{l}\text { n.d. } \\
0,089 \mathrm{~b} \\
0,069 \mathrm{ab} \\
0,036 \mathrm{a}\end{array}$ & $\begin{array}{c}\text { n.d. } \\
0,050 \text { a } \\
0,041 \text { a } \\
0,019 \text { a }\end{array}$ & $\begin{array}{l}\text { n.d. } \\
0,076 \mathrm{~b} \\
0,070 \mathrm{ab} \\
0,039 \mathrm{a}\end{array}$ & $\begin{array}{l}\text { n.d. } \\
0,047 \mathrm{~b} \\
0,035 \mathrm{ab} \\
0,012 \mathrm{a}\end{array}$ \\
\hline
\end{tabular}

Analiza statystyczna została przeprowadzona oddzielnie dla każdej substancji czynnej, sezonu i terminu analiz. Średnie oznaczone w kolumnach tą samą literą nie różnią się istotnie według testu Newmana-Keulsa przy $\mathrm{p}=0,05$

Statistical analysis was performed separately for each active substance, season and date of analyses. Means in columns followed by the same letter are not significantly different according to the Newman-Keuls test at $\mathrm{p}=0.05$

n.d. - nie wykryto - not detected

Analiza pozostałości pestycydów w jabłkach po zbiorach wykazała, że po trzykrotnym zastosowaniu środka Bellis 38 WG lub Switch 62,5 WG, pozostałości substancji czynnych były znacznie wyższe niż po jednorazowej aplikacji (tab. 4-5). Stwierdzono jednak, że nawet trzykrotne $(21,14$ i 7 dni) zastosowanie środka Bellis 38 WG przed zbiorem nie powodowało przekroczenia norm Unii Europejskiej (Rozporządzenie 2005) w odnie- sieniu do obu składników preparatu: boskalidu i piraklostrobiny (NDP, odpowiednio: 2,0 i $0,3 \mathrm{mg} / \mathrm{kg}$ ) oznaczonych bezpośrednio po zbiorze jabłek. Poziom pozostałości boskalidu w owocach ze wszystkich kombinacji doświadczalnych nie przekraczał w czasie zbioru $0,4 \mathrm{mg} / \mathrm{kg}$, a piraklostrobiny $0,1 \mathrm{mg} / \mathrm{kg}$, uwzględniając niepewność rozszerzoną wyników (tab. 4). Również w przypadku środka Switch 62,5 WG zastosowanego jednorazowo 
Tabela 5. Poziom pozostałości cyprodynilu i fludioksonilu w jabłkach odmiany Szampion, po zbiorze i po przechowywaniu, w zależności od liczby i terminów zabiegów preparatem Switch 62,5 WG

Table 5. Cyprodinil and fludioxonil residues in apple cultivar Shampion after harvest and after cold storage, depending on the number and dates of Switch $62,5 \mathrm{WG}$ treatments

\begin{tabular}{|c|c|c|c|c|c|}
\hline \multirow{3}{*}{$\begin{array}{c}\text { Liczba } \\
\text { zabiegów } \\
\text { The number } \\
\text { of treatments }\end{array}$} & \multirow{3}{*}{$\begin{array}{l}\text { Terminy zabiegów } \\
\text { (dni przed zbiorem) } \\
\text { Dates of treatments } \\
\text { (days before harvest) }\end{array}$} & \multicolumn{2}{|c|}{$\begin{array}{l}\text { Sezon } 2012 / 2013 \\
\text { Season } 2012 / 2013\end{array}$} & \multicolumn{2}{|c|}{$\begin{array}{l}\text { Sezon } 2013 / 2014 \\
\text { Season } 2013 / 2014\end{array}$} \\
\hline & & \multicolumn{4}{|c|}{$\begin{array}{l}\text { terminy analiz pozostałości fungicydów } \\
\text { dates of fungicide residues analyses }\end{array}$} \\
\hline & & $\begin{array}{l}\text { po zbiorze } \\
\text { after harvest }\end{array}$ & $\begin{array}{l}\text { po przechow. } \\
\text { after storage }\end{array}$ & $\begin{array}{l}\text { po zbiorze } \\
\text { after harvest }\end{array}$ & $\begin{array}{l}\text { po przechow. } \\
\text { after storage }\end{array}$ \\
\hline \multicolumn{6}{|c|}{ Pozostałości cyprodynilu - Cyprodinil residues [mg/kg] } \\
\hline $\begin{array}{l}0 \\
3 \\
2 \\
1 \\
1\end{array}$ & $\begin{array}{c}- \\
21,14,7 \\
14,7 \\
7 \\
3\end{array}$ & $\begin{array}{c}\text { n.d. } \\
0,412 \mathrm{~d} \\
0,192 \mathrm{c} \\
0,061 \mathrm{a} \\
0,139 \mathrm{~b}\end{array}$ & $\begin{array}{c}\text { n.d. } \\
0,204 \mathrm{~d} \\
0,127 \mathrm{~cd} \\
0,038 \mathrm{a} \\
0,070 \mathrm{~b}\end{array}$ & $\begin{array}{l}\quad \text { n.d. } \\
0,345 \mathrm{~d} \\
0,302 \mathrm{~cd} \\
0,182 \mathrm{a} \\
0,287 \mathrm{~b}\end{array}$ & $\begin{array}{c}\text { n.d. } \\
0,269 \mathrm{c} \\
0,194 \mathrm{~b} \\
0,134 \mathrm{a} \\
0,165 \mathrm{ab}\end{array}$ \\
\hline \multicolumn{6}{|c|}{ Pozostałości fludioksonilu - Fludioxonil residues [mg/kg] } \\
\hline $\begin{array}{l}0 \\
3 \\
2 \\
1 \\
1\end{array}$ & $\begin{array}{c}- \\
21,14,7 \\
14,7 \\
7 \\
3\end{array}$ & $\begin{array}{c}\text { n.d. } \\
0,374 \mathrm{c} \\
0,147 \mathrm{~b} \\
0,060 \mathrm{a} \\
0,171 \mathrm{~b}\end{array}$ & $\begin{array}{c}\text { n.d. } \\
0,140 \mathrm{c} \\
0,076 \mathrm{~b} \\
0,036 \mathrm{a} \\
0,083 \mathrm{~b}\end{array}$ & $\begin{array}{c}\text { n.d. } \\
0,232 \mathrm{c} \\
0,173 \mathrm{~b} \\
0,122 \mathrm{a} \\
0,186 \mathrm{~b}\end{array}$ & $\begin{array}{c}\text { n.d. } \\
0,169 \mathrm{c} \\
0,102 \mathrm{~b} \\
0,058 \mathrm{a} \\
0,085 \mathrm{~b}\end{array}$ \\
\hline
\end{tabular}

Analiza statystyczna została przeprowadzona oddzielnie dla każdej substancji czynnej, sezonu i terminu analiz. Średnie oznaczone w kolumnach tą samą literą nie różnią się istotnie według testu Newmana-Keulsa przy $\mathrm{p}=0,05$

Statistical analysis was performed separately for each active substance, season and date of analyses. Means in columns followed by the same letter are not significantly different according to the Newman-Keuls test at $p=0.05$ n.d. - nie wykryto - not detected

(3 lub 7 dni), dwukrotnie (14 i 7 dni) oraz trzykrotnie (21, 14 i 7 dni) przed zbiorem poziom pozostałości substancji czynnych: cyprodynilu i fludioksonilu, oznaczonych bezpośrednio po zbiorze owoców, był znacznie poniżej norm obowiązujących w Unii Europejskiej, dla których NDP wynosi odpowiednio: 1,0 i $5,0 \mathrm{mg} / \mathrm{kg}$ (Rozporządzenie 2005). Poziom pozostałości cyprodynilu oraz fludioksonilu w jabłkach ze wszystkich kombinacji doświadczalnych nie przekraczał w czasie zbioru $0,5 \mathrm{mg} / \mathrm{kg}$, uwzględniając niepewność rozszerzoną wyników (tab. 5).

Należy jednak zaznaczyć, że jabłka z powyższych kombinacji doświadczalnych nie spełniały wymagań Dyrektywy Komisji 2006/141/WE. Owoce poddane zabiegom badanymi fungicydami zawierały w czasie zbioru pozostałości przekraczające $0,01 \mathrm{mg} / \mathrm{kg}$.

Pozostałości badanych fungicydów zostały wykryte również $\mathrm{w}$ jabłkach po 6 miesiącach przechowywania. Ich zawartość była jednak niższa w porównaniu do oznaczonej bezpośrednio po zbiorze (tab. 4-5). Jabłka te spełniały wymagania Rozporządzenia (WE) nr 396/2005 odnośnie najwyższych dopuszczalnych poziomów pestycydów, nie spełniały jednak w dalszym ciągu wymagań stawianych produktom żywnościowym przeznaczonym dla niemowląt i małych dzieci, zgodnie z Dyrektywą Komisji 2006/ 141/WE. Średnia redukcja badanych fungicydów w czasie 6-miesięcznego przechowywania jabłek w chłodni wynosiła od 30 do $60 \%$ w obu sezonach badawczych. Wcześniejsze badania również wykazały redukcję kaptanu i tiuramu podczas przechowywania jabłek traktowanych przed zbiorem odpowiednio: środkiem Captan 80 WG lub Thiram Granuflo 80 WG (Szymczak i wsp. 2013).
Pozostałości kaptanu podczas 6-miesięcznego przechowywania jabłek obniżały się od 30 do $50 \%$, a $\mathrm{CS}_{2}$ od 30 do $70 \%$. Ticha i wsp. (2008) również stwierdzili znaczny spadek pozostałości pestycydów w czasie 5-miesięcznego przechowywania jabłek w chłodni zwykłej (temperatura $1-3^{\circ} \mathrm{C}$ ), prawie wszystkie pestycydy oznaczone w trakcie zbioru uległy rozkładowi do ilości śladowych lub poniżej granicy oznaczalności. Taki rozkład mógł być spowodowany niskim poziomem pestycydów oznaczonych w owocach bezpośrednio po zbiorze. Szymczak i wsp. (2013) stwierdzili, że im wyższy początkowy poziom pozostałości pestycydów w owocach tym niższe tempo ich rozkładu podczas przechowywania. Zdaniem Bryk i wsp. (2005) tempo rozkładu w czasie przechowywania zależy od rodzaju pestycydu i warunków przechowywania owoców. Metody aplikowania fungicydów również wpływają na szybkość degradacji substancji czynnych w przechowywanych jabłkach. Gdy fungicydy były nanoszone po zbiorze jabłek poprzez zanurzenie owoców w roztworze (metoda nielegalna w Polsce), ich rozkład podczas przechowywania był minimalny lub nie zachodził w ogóle. Zostało to stwierdzone przez Bryk i wsp. (2005) w przypadku tolilofluanidu i trifloksystrobiny oraz przez Xiao i Boal (2009) w przypadku fludioksonilu i pirymetanilu.

\section{Wnioski / Conclusions}

1. Fungicydy Bellis $38 \mathrm{WG}$ (boskalid + pyraklostrobina) i Switch 62,5 WG (cyprodynil + fludioksonil) zastosowane w okresie przedzbiorczym hamowały występo- 
wanie gorzkiej zgnilizny jabłek (powodowanej przez Neofabraea spp.) w czasie przechowywania w chłodni zwykłej.

2. Dwu- lub trzykrotne zastosowanie środków Bellis 38 WG i Switch 62,5 WG było bardziej skuteczne w ograniczaniu gorzkiej zgnilizny jabłek niż jednokrotne. Najwyższą efektywność w zwalczaniu gorzkiej zgnilizny jabłek zaobserwowano po trzykrotnej aplikacji każdego z badanych fungicydów.
3. Pozostałości boskalidu, pyraklostrobiny, cyprodynilu i fludioksonilu oznaczone w jabłkach w czasie zbioru były skorelowane $\mathrm{z}$ liczbą $\mathrm{i}$ terminami stosowania fungicydów, jednak nawet po trzykrotnej aplikacji środków nie zostały przekroczone najwyższe dopuszczalne poziomy obowiązujące w Unii Europejskiej.

4. Poziom pozostałości boskalidu, pyraklostrobiny, cyprodynilu i fludioksonilu w jabłkach po 6 miesiącach przechowywania w chłodni zwykłej istotnie się obniżył, ale oznaczone ilości wynosiły powyżej $0,01 \mathrm{mg} / \mathrm{kg}$.

\section{Literatura / References}

Blažek J., Kloutvorova J., Krelinova J. 2006. Incidence of storage diseases on apples of selected cultivars and advanced selections grown with and without fungicide treatments. Horticulural Science 33: 87-94.

Bryk H. 2010. Choroby przechowalnicze jabłek i gruszek. s. 17-26. W: VI Międzynarodowe Targi Agrotechniki Sadowniczej. Warszawa, 15-16.01.2010, 162 ss.

Bryk H., Miszczak A., Nowacki J. 2005. Dynamika zanikania wybranych fungicydów w jabłkach podczas przechowywania w zależności od sposobu aplikacji. [The dynamics of fungicides degradation in stored apples depending on the method of application]. Progress in Plant Protection/Postępy w Ochronie Roślin 45 (2): 593-596.

Bryk H., Rutkowski K.P. 2012. Skuteczność proekologicznych metod ochrony jabłek przed gorzką zgnilizną (Pezicula spp.). [Efficacy of alternative methods in controlling of bull's eye rot (Pezicula spp.)]. Progress in Plant Protection/Postępy w Ochronie Roślin $52(3): 727-732$

Dell J.R., Prange R.K. 1993. Postharvest physiological disorders, diseases and mineral concentrations of organically and conventionally grown McIntosh and Cortland apples. Canadian Journal of Plant Science 73 (1): 223-230.

Dyrektywa Komisji 2006/141/WE z dnia 22 grudnia 2006 r. w sprawie preparatów do początkowego żywienia niemowląt i preparatów do dalszego żywienia niemowląt oraz zmieniająca Dyrektywę 1999/21/WE (Dz. Urz. UE L401 z 30.12.2006). http:// eur-lex.europa.eu/legal-content/PL [dostęp: 22.06.2015].

Jones A.L., Ehret G.R., Meyer M.P., Shane W.W. 1996. Occurrence of bitter rot on apple in Michigan. Plant Disease 80: $1294-1297$.

Neri F., Mari M., Brigati S., Bertolini P. 2009. Control of Neofabraea alba by plant volatile compounds and hot water. Postharvest Biology and Technology 51 (3): 425-430.

PN-EN 15662: 2008. Żywność pochodzenia roślinnego. Oznaczanie pozostałości pestycydów metodą GC-MS i/lub LC-MS(MS) po uprzedniej ekstrakcji i rozdziale acetonitrylem oraz oczyszczaniu metodą dyspersyjnej SPE. Metoda QuEChERS, 81 ss.

Poulsen M.E., Naef A., Gasser S., Christen D., Rasmussen P.H. 2009. Influence of different disease control pesticide strategies on multiple pesticide residue levels in apple. Journal of Horticultural Science \& Biotechnology, No. ISAFRUIT Special Issue: 58-61.

Rozporządzenie 2005. Rozporządzenie (WE) nr 396/2005 Parlamentu Europejskiego i Rady z dnia 23 lutego 2005 r. w sprawie najwyższych dopuszczalnych poziomów pozostałości pestycydów w żywności i paszy pochodzenia roślinnego i zwierzęcego oraz na ich powierzchni, zmieniające Dyrektywę Rady 91/414/EWG (Dz. Urz. L 70 z 16.03.2006 r. z późn. zm.). http:// eurl-lex.europa.eu/legal-content/PL [dostęp: 22.06.2015].

SANCO 2011. Method validation and quality control procedures for pesticide residues analysis in food and feed. SANCO/12495/2011, 40 pp. http://www.eurl-pesticides.eu [Accessed: June 22, 2015].

SANCO 2013. Guidance document on analytical quality control and validation procedures for pesticide residues analysis in food and feed. SANCO/12571/2013, 46 pp. http://www.eurl-pesticides.eu [Accessed: June 22, 2015].

Spotts R.A. 1990. Bull's eye rot. p. 56 In: "Compendium of Apple and Pear Diseases" (A.L. Jones, H.S. Aldwincle, eds.). APS Press, St. Paul MN, 100 pp.

Szymczak J.A., Bryk H., Miszczak A. 2013. Wpływ wybranych fungicydów stosowanych w różnych terminach na poziom ich pozostałości w jabłkach oraz ochronę przed chorobami przechowalniczymi. [The influence of selected fungicides used at different dates on residues in apples and protection against storage diseases]. Progress in Plant Protection/Postępy w Ochronie Roślin 53 (3): $586-592$

Ticha J., Hajslowa J., Jech M., Honzicek J., Lacina O., Kohoutkova J., Kocourek V., Lansky M., Kloutvorova J., Falta V. 2008. Changes of pesticide residues in apples during cold storage. Food Control 19 (3): 247-256.

WAPA 2014. The World Apple and Pear Association. http://wapa-association.org [Accessed: June 22, 2015].

Weber R. 2009. Apple storage rots: the situation in Northern Germany. p. 1-2. In: COST 864 Expert Meeting. Norway, Bergen, 25-26 March 2009, $32 \mathrm{pp}$

Weiss A., Mögel G., Kunz S. 2006. Development of „Boni-Protect” - a yeast preparation for use in the control of postharvest diseases of apples. p. 113-117. In: Proceedings 12th International Conference on Cultivation Technique and Phytopathological Problems in Organic Fruit-Growing. Germany, Hohenheim, 31 January-2 February 2006, 249 pp.

Wyszukiwarka środków ochrony roślin. 2015. Biuletyn Informacji Publicznej Ministerstwa Rolnictwa i Rozwoju Wsi [online]. http://bip.minrol.gov.pl/Informacje-Branzowe/Produkcja-Roslinna/Ochrona-Roslin/Wyszukiwarka-srodkow-ochrony-roslin [dostęp: 22.06.2015].

Xiao C.L., Boal R.J. 2009. Residual activity of fludioxonil and pyrimethanil against Penicillium expansum on apple fruit. Plant Disease 93 (10): 1003-1008. 